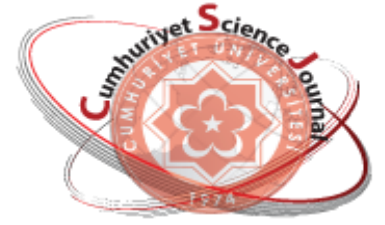

e-ISSN: $2587-246 X$

ISSN: 2587-2680

\section{Cumburiyot Seionee Journal}

esj

Cumhuriyet Sci. J., Vol.40-1(2019) 125-135

\title{
Curcumin-Loaded Bio-Based Electrospun Polyurethane Scaffolds
}

\author{
Nesrin HORZUM POLAT ${ }^{1,2 *(D)}$, Nehir Artk KINALI ${ }^{2}$ (D) \\ ${ }^{I}$ Izmir Katip Celebi University, Faculty of Engineering and Architecture, Department of Engineering Sciences, \\ Izmir, TURKEY \\ ${ }^{2}$ Izmir Katip Celebi University, Graduate School of Natural and Applied Sciences, Department of Biocomposite \\ Engineering Graduate Program, Izmir, TURKEY
}

\begin{abstract}
Polymeric electrospun fibers present well-design scaffolds for wound healing applications. Here, the fabrication of biobased polyurethane (PU) blend fibers containing curcumin (Cur) was reported. Not only polymer concentration but also curcumin concentration affects the morphology, diameter, and contact angle values of the fibers. Morphological investigations revealed that the diameter and hydrophilicity of the PU fibers increased upon addition of curcumin. Effect of process parameters (applied voltage, flow rate, and tipto-collector distance) on the average diameter and the hydrophilicity of the PU and PU/Cur fibers were examined. Optimum conditions to obtain uniform and bead-free PU/Cur fibers were determined as $12.5 \mathrm{kV}, 1$ $\mathrm{mL} / \mathrm{h}$, and $17 \mathrm{~cm}$. This study demonstrates that the electrospinning process provides a simple way of obtaining bioactive agent loaded fibrous scaffolds, as well as contributing to a better understanding of the effect of process variables in the fabrication of PU/Cur blend fibers for wound healing applications.
\end{abstract}

Keywords: Biomaterials, bio-based polyurethane, curcumin, electrospinning, fibers, wound healing.

\section{Kurkumin Yüklü Biyo-Bazlı Elektroeğirme Poliüretan Yapılar}

\begin{abstract}
Özet. Polimerik elektroeğirme lifler, yara iyileşme uygulamaları için iyi tasarımlı iskeleler sunmaktadır. Burada, kurkumin (Cur) içeren biyobazlı poliüretan (PU) karışım liflerin üretimi rapor edilmektedir. Yalnızca polimer konsantrasyonu değil, aynı zamanda kurkumin konsantrasyonu, fiberlerin morfolojisi, çapı ve temas açısı değerlerini etkilemiş̧tir. Morfolojik araştırmalar, PU liflerinin çapının ve hidrofilikliğinin kurkumin ilavesi üzerine arttığını ortaya koymuştur. Proses parametrelerinin (uygulanan voltaj, akış hızı ve uçtan toplayıcıya mesafe) PU ve PU/Cur liflerinin ortalama çap ve hidrofilikliği üzerindeki etkileri incelenmiştir. Homojen ve boncuksuz PU/Cur lif elde etmek için optimum koşullar $12.5 \mathrm{kV}, 1 \mathrm{~mL} / \mathrm{s}$ ve $17 \mathrm{~cm}$ olarak belirlenmiştir. Bu çalışma, elektroeğirme işleminin, biyoaktif madde yüklü lifli iskeleleri elde etmenin basit bir yolunu sağlamasının yanı sıra, PU/Cur karışım liflerinin imalatında yara iyileşmesi uygulamaları için işlem değişkenlerinin etkisinin daha iyi anlaşılmasına katkıda bulunduğunu göstermektedir.
\end{abstract}

Anahtar Kelimeler: Biyomalzemeler, biyo-tabanlı poliüretan, kurkumin, elektroeğirme, lifler, yara iyileşmesi

\section{INTRODUCTION}

Along with the increased role of nanotechnology in multidisciplinary research, electrospinning technique has become a significant step in the fabrication of nano/microfibers. This technique provides the fabrication of fibrous mats from both organic and/or inorganic materials and finds their potential applications in the field of biosensors, drug delivery, tissue engineering, and wound dressing. Electrospun scaffolds mimic extracellular matrix (ECM) since it has a fiberlike structure with a highly effective surface for

\footnotetext{
* Corresponding author. Email address: nesrin.horzum.polat@ikc.edu.tr

http://dergipark.gov.tr/csj C2016 Faculty of Science, Sivas Cumhuriyet University
} 
adhesion and cell growth. It is well known that an ideal scaffold should act like an ECM, as structural and biological functions, which is responsible of regulating cellular activities and mechanical support.

Many biomaterials such as alginate, cellulose, chitosan, collagen, and poly ( $\varepsilon$-caprolactone) are promising for biomedical applications [1]. Medicinal plant extracts, spices, and essential oils have also been used as biologically active agents for personal care, pharmaceuticals, and foodprocessing applications [2-4]. Curcumin (Cur) is one of the most widely used spices for the treatment of many inflammatory wounds and other diseases [5]. Cur, which is obtained from the rhizomes of Curcuma longa, has most of the pharmaceutical properties such as antioxidant [6], anti-inflammatory [7], hypoglycemic effect [8], antitumor [9], anti-HIV [10], induces apoptosis of damaged hepatocytes[11] and wound healing activities [12].

There are many researchers working on electrospun nanofibers to develop scaffolds for wound dressing and tissue engineering [13-15]. Dhurai et al. [16, 17] fabricated the Cur-loaded chitosan and chitosan/PLA nanofibers, and tested their suitability for wound healing. The results showed the reduction of wound area due to the presence of both Cur and chitosan. Curincorporated electrospun nanofibers of a blend of poly (lactic acid) (PLA) and hyperbranched polyglycerol (HPG) were used for a potential wound patch dressing for acute and chronic wound dressing [18]. Fabrication of Cur-loaded poly(3-hydroxy butyric acid-co-3-hydroxy valeric acid) (PHBV) nanofiber-based wound dressing materials was reported by Mutlu et al. [19], who found that PHBV and PHBV/Cur nanofibers enhanced the cell attachment and proliferation. Shababdoust et. al. [20] described the fabrication of Cur-loaded polycaprolactone (PCL) (with two different molecular weights; 2000 and $530 \mathrm{Da}$ )-based polyurethane (PU) substrate. They demonstrated that Cur-loaded PU synthesized by PCL with a molecular weight of 2000 Da showed better mechanical properties as well as better antibacterial properties for wound dressing applications. Sedhgi et.al. [21] fabricated electrospun nanofibers with using graphene oxide (GO) and $\mathrm{Zn}$-Cur complex, and they investigated the capacity of the Zn-Cur scaffolds for bone regeneration. They reported that the Zn-Cur composite nanofibers with advanced osteogenic capacity and cytocompatibility were promising for bone tissue engineering. In a very recent work, Li et. al [22] have presented the formation of the sandwich structure composite (SSC) membranes which have three layers, including polyvinylidene fluoride fibrous layer (bottom), Cur/PLA microsphere layer (middle), and the enrofloxacin/PLA fibrous layer (top), respectively. The drug-loaded SSC membranes showed a precise antioxidant activity against $\bullet \mathrm{OH}$ and diphenyl picryl hydrazinyl (DPPH) free radicals, and antibacterial activity against Staphylococcus aureus, Escherichia coli, Streptococcus pneumonia, Pseudomonas aeruginosa, and Candida albicans.

Electrospun fibers also provide some advantages such as cost-effective, high surface area, high loading or encapsulation capacity, and the increased bioavailability of the drug [23]. From the structural point of view, processing, solution, and environmental parameters affect the morphology of the fibers formed. The fabrication of electrospun nanofibers from biopolymers is preferred because of their biocompatibility, biodegradability, non-toxicity, and antimicrobial activity [24, 25]. PU is one of the most commonly used polymers in electrospinning because of its good barrier properties, oxygen permeability, biocompatibility, and easy availability, and it has been studied as a wound dressing material for many years [26]. The fiber scaffolds we present in this paper are electrospun from a blend of Cur and bio-based polyurethane (PU) in $N, N$-dimethylformamide (DMF) as a solvent. This study demonstrates that electrospinning provides a simple way to obtain fibrous scaffolds containing bioactive agents and can also contribute to a better understanding of the effect of process variables on the fabrication 
of PU/Cur blend fibers for further use in wound healing applications.

\section{MATERIALS AND METHODS}

\section{Materials}

Bio-based polyurethane (PU) with a product name of (Pearlthane ${ }^{\circledR}$ ECO D12T85, Lubrizol) was used as a raw material for biopolymer matrix and $N, \quad N$-dimethylformamide (DMF, SigmaAldrich) was used as a solvent. Curcuma longa (Turmeric) (Cur, Sigma) was added as a bioactive agent. All the reagents were used without further purification.

\section{Preparation of the Electrospinning Solutions}

The polymer solutions were prepared by dissolving the PU in DMF at the concentrations of $5,10,12.5$, and $15 \mathrm{wt} \%$ under magnetic stirring for 24 hours at room temperatue. Cur was added at the different concentrations $(1,5$, and 10 wt \%) into the $12.5 \mathrm{wt} \%$ PU solutions and left for 24 hours under stirring.

\section{Fabrication of PU and PU/Cur Scaffolds}

PU and PU/Cur fibers were fabricated via a commercial electrospinning platform (Inovenso Basic Setup) covered with a polycarbonate cabinet for safety and avoiding from air convection.

The solutions of PU and PU/Cur were filled in the $5 \mathrm{~mL}$ plastic syringes. The positive electrode was applied to the spinneret; a rectangular stainless-steel plate was used as a collector which was covered by an aluminum foil for counter electrode. Electrospinning of the solutions was performed with a flow rate of $1.0-1.5 \mathrm{~mL} / \mathrm{h}$, applied voltage of $10-15 \mathrm{kV}$, and tip-to-collector distance of 14-20 cm. The electrospinning parameters are given in Table 1. The working conditions were performed at ambient conditions. $\left(55 \% \mathrm{RH}, 25^{\circ} \mathrm{C}\right)$.

Table 1. Electrospinning parameters used to fabricate the PU and PU/Cur fibers.

\begin{tabular}{lllll}
\hline Solutions (wt\%) & Applied voltage $(\mathrm{kV})$ & Flow rate & $(\mathrm{mL} / \mathrm{h})$ & Tip-to-collector distance $(\mathrm{cm})$ \\
\hline $\mathrm{PU}(5,10,12.5$, and 15) & 12.5 & 1.00 & & 17.0 \\
$\mathrm{PU}(12.5) /$ Cur $(1,5,10)$ & 12.5 & 1.00 & 17.0 \\
$\mathrm{PU}(12.5) /$ Cur (5) & $10.0-12.5-15.0$ & $1.00-1.25-1.50$ & $14.0-17.0-20.0$ \\
\hline
\end{tabular}

\section{Characterization of PU and PU/Cur Scaffolds}

To determine the surface morphology of the fibers, scanning electron microscopy (SEM) was performed using Carl Zeiss $300 \mathrm{VP}$ and fiber diameters were calculated by Fiji ImageJ software. In order to evaluate the hydrophilicity of the fibers, the water contact angle (CA) was measured by a Theta Lite Optical Tensiometer, (Finland). Sessile drops of $4 \mu \mathrm{L}$ of water were deposited on the surface of the fibrous scaffolds and the measurements were conducted at least three different sample areas and averaged for each sample. X-ray diffraction (XRD) patterns of fiber samples were recorded in a Philips X'Pert Pro Xray diffractometer using $\mathrm{CuK} \alpha$ radiation $(\lambda=$ $1.5418 \AA$ A). $\quad$ Fourier transform infrared spectroscopy (FTIR, Thermo Scientific ${ }^{\mathrm{TM}}$ Nicolet $^{\mathrm{TM}}$ iS ${ }^{\mathrm{TM}} 5$ ) was performed for $\mathrm{PU}$ and PU/Cur blend fibers.

\section{RESULTS AND DISCUSSSON}

The optimization of fiber fabrication by electrospinning depends on various factors which affect the formation of fibers, including solution, process, and environmental parameters. PU and PU/Cur fibrous mats were fabricated by electrospinning PU and PU/Cur solutions in DMF with different PU and Cur concentrations. The effects of solution concentrations, applied voltage, flow rate, and tip-to-collector distance on the morphology of the PU and PU/Cur fibers were investigated. The surface hydrophilicity was also 
examined for further applications of the fibrous scaffolds as a wound dressing.

\section{Effect of PU and Cur Concentration}

Solvent type, solution concentration, viscosity, and conductivity are the important solution parameters for electrospinning. The stretching of a charged jet is significantly influenced by varying the electrospinning solution concentration. As a general rule, at low polymer concentration, the applied electrical field and surface tension lead to the disintegration of the entangled polymer chains and result in bead or beaded fiber formation [27]. As the concentration of the polymer in the solution increases, fiber diameter also increases. The increase in the fiber diameters can be attributed to the increase in viscosity of the electrospinning solution. When the enhanced chain entanglements overcome the surface tension of the droplet, uniformly distributed bead-free fibers can be obtained [28].

Figure 1 (a-d) shows the changes in morphology of the fibers with an increasing amount of PU in DMF. The low polymer concentration (5 wt $\%$ ) resulted in the beaded fibrous structure (Figure 1a). Furthermore, the bead density decreased with the increasing PU concentration beyond $5 \mathrm{wt} \%$ and bead-free fibers were collected. The average diameters and surface contact angles of PU fibers were demonstrated in Figure 1(e-f). The diameters of the fibers obtained from 5, 10, 12.5 and $15 \mathrm{wt} \%$ $\mathrm{PU} / \mathrm{DMF}$ solutions are $250 \pm 80,370 \pm 130,480$ \pm 150 , and $850 \pm 250 \mathrm{~nm}$, respectively. An exponential growth with the polymer content was observed, transferred PU content from tip-tocollector was increased, and hence thicker fibers are obtained.

The wettability of the PU fibers obtained from 5, 10, 12.5 and $15 \mathrm{wt} \% \mathrm{PU} / \mathrm{DMF}$ solutions are measured as $72 \pm 7^{\circ}, 92 \pm 4^{\circ}, 94 \pm 5^{\circ}$, and $96 \pm$ $3^{\circ}$, respectively. PU fibers exhibit a hydrophilic nature when the PU content is $5 \mathrm{wt} \%$. As the concentration of PU increases from 10 to $15 \mathrm{wt} \%$, the water contact angle increases, indicating the hydrophobicity. This can be explained by the changing ratio of adhesive forces (polymersolvent) and cohesive forces (solvent-solvent). When adhesive forces are less than cohesive forces, the contact angle is higher than 90 degrees, tends not to wet the surface of the scaffold [29]. In addition, taking the diameter of the PU fibers into consideration, it has been observed that the increment in the concentration affects not only the fiber diameters but also the porosity (originated by the fiber network) which may be related to the increase in hydrophobicity.
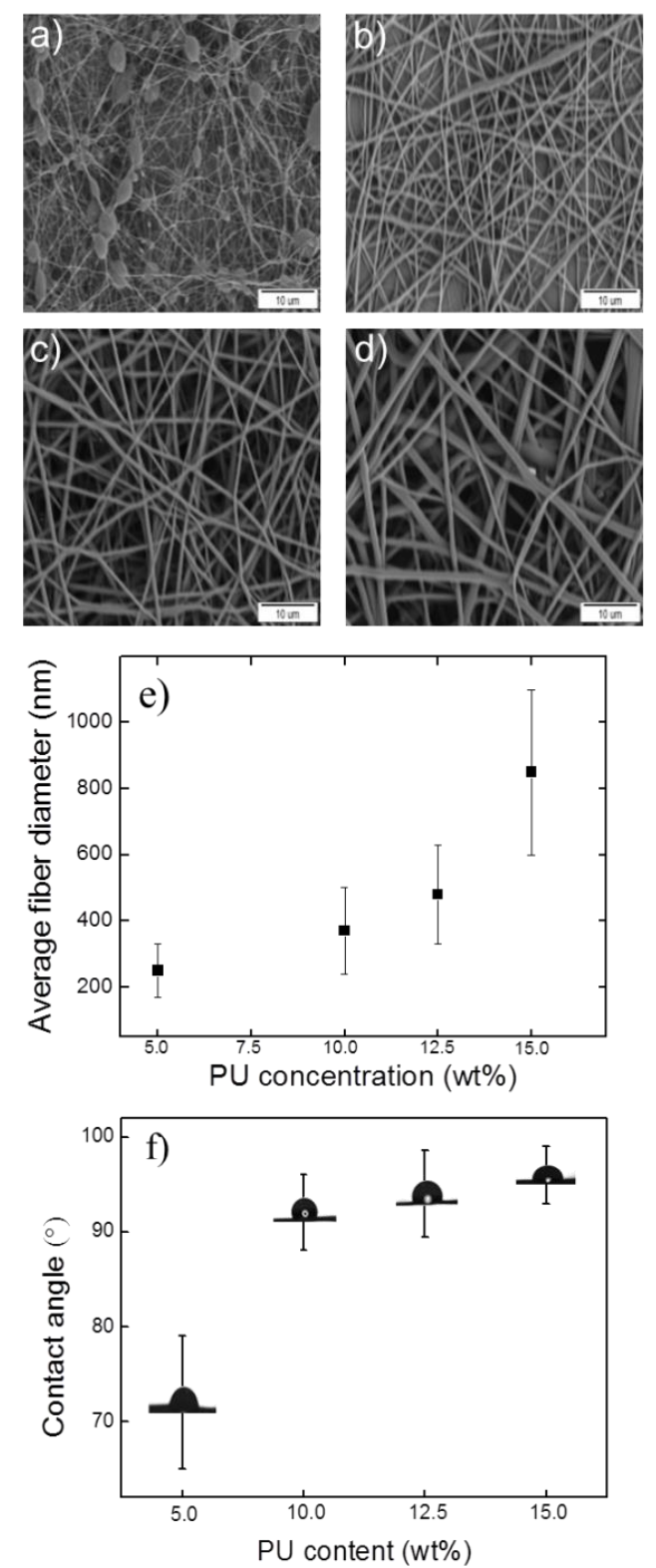

Figure 1. SEM micrographs of PU fibers obtained from electrospinning a) $5 \mathrm{wt} \%$, b) $10 \mathrm{wt} \%$, c) $12.5 \mathrm{wt} \%$, and d) 15 wt $\%$ PU/DMF solutions. e) Average fiber diameter and f) contact angle of the fibers as functions of PU weight fraction. (Applied voltage: $12.5 \mathrm{kV}$, Flow rate: $1.00 \mathrm{~mL} / \mathrm{h}$, Distance: $17 \mathrm{~cm})$. 
Besides PU fibers, Cur-loaded PU fibers were also fabricated. SEM micrographs as well as photographic images, average fiber diameters, and contact angles of the fibers are shown in Figure 2. The morphology of the fibers are smooth however, as Cur content is increased, nonuniformly distributed bead-free fibers with larger diameters are obtained because of the increased viscosity. (Figure 2 (a-d)) Furthermore, higher Cur content results in fiber sticking together. The diameters of the blend fibers containing $0,1,5$, and $10 \mathrm{wt} \%$ Cur are $480 \pm 150,525 \pm 70,960 \pm$ 210 , and $780 \pm 155 \mathrm{~nm}$, respectively. (Figure 2e) When the Cur concentration is $10 \mathrm{wt} \%$, solution viscosity can be considered above the optimum value for the fiber formation that Cur is no longer able to penetrate into the fiber. As already shown in the photographic images of the blend fibers, free droplets are observed around the fiber mat containing $10 \mathrm{wt} \%$ Cur. A similar trend was observed for the diameter of curcumin-loaded PCL/chitosan [30], polyurethane [20] and cellulose acetate [14] fibers. The resultant thicker fibers with the addition of curcumin were attributed to the higher viscosity of the electrospinning solution and lower solvent evaporation rate. However, reduced diameter of the fibers with the increased curcumin content has also been reported by some researchers [19, 31]. The addition of curcumin leads to a decrease in the polymer concentration and enhance the conductivity of the blend solution, hence thinner fibers are obtained by overcoming the surface tension and stretching easily. This conflict may be interpreted as the differences in the used polymer/solvent combinations. Table 2 also includes the effect of curcumin addition on the properties of electrospun fibers for given system parameters.

The contact angles of the blend fibers containing $0,1,5$, and $10 \mathrm{wt} \%$ Cur are $94 \pm 5^{\circ}, 90 \pm 0.5^{\circ}, 88$ $\pm 1.4^{\circ}$, and $92 \pm 1.7^{\circ}$, respectively. In general, the water contact angle relatively decreases with the addition of Cur, (Figure 2f) indicating that Cur has higher wettability than that of PU, due to the presence of hydrophilic functional groups. Fallah et al. reported that PCL/gelatin nanofibers became more hydrophilic by the incorporation of curcumin [32].

Table 2. Overview of the curcumin-loaded electrospun fibers in literature.

\begin{tabular}{|c|c|c|c|c|c|c|}
\hline Samples & Curcumin content $(\%)$ & Solvent & AFD (nm) & $\mathrm{CA}\left({ }^{\circ}\right)$ & $\begin{array}{c}\text { Electrospinning } \\
\text { parameters }\end{array}$ & Ref. \\
\hline $\begin{array}{l}\text { PLA } \\
10 \%(\mathrm{wt} / \mathrm{v}) \\
\text { PLA/HPG } \\
10 / 20 \%(\mathrm{wt} / \mathrm{v})\end{array}$ & 10.0 & $\begin{array}{l}\text { Chloroform } \\
\text { /methanol }\end{array}$ & $\begin{array}{l}516 \pm 174 \\
601 \pm 194\end{array}$ & $\begin{array}{l}108 \pm 1 \\
113 \pm 3\end{array}$ & $\begin{array}{l}13-15 \mathrm{kV} \\
0.5 \mathrm{~mL} / \mathrm{h} \\
12 \mathrm{~cm}\end{array}$ & {$[18]$} \\
\hline $\begin{array}{l}\text { PHBV } \\
10 \%(w / v)\end{array}$ & \begin{tabular}{l|}
0 \\
0.1 \\
0.3 \\
0.5
\end{tabular} & $\begin{array}{l}\text { Chloroform } \\
\text { /DMF }\end{array}$ & $\begin{array}{l}519 \pm 15 \\
304 \pm 94 \\
215 \pm 48 \\
207 \pm 56\end{array}$ & - & $\begin{array}{l}17 \mathrm{kV} \\
0.6 \mathrm{~mL} / \mathrm{h} \\
20 \mathrm{~cm}\end{array}$ & [19] \\
\hline $\begin{array}{l}\text { PU2000 } \\
20(\mathrm{wt} \%) \\
\text { PU530 } \\
30(\mathrm{wt} \%)\end{array}$ & $\begin{array}{l}0 \\
5.0 \\
10.0 \\
0 \\
5.0 \\
\end{array}$ & HFIP & $\begin{array}{l}172 \pm 64 \\
256 \pm 110 \\
274 \pm 107 \\
200 \pm 80 \\
284 \pm 112\end{array}$ & $\begin{array}{l}85.8 \pm 2.6(\text { film}) \\
97.0 \pm 1.2(\text { film })\end{array}$ & $\begin{array}{l}20 \mathrm{kV} \\
0.5 \mathrm{~mL} / \mathrm{h} \\
21 \mathrm{~cm}\end{array}$ & [20] \\
\hline $\begin{array}{l}\text { Almond gum/PVA } \\
8 \%(\mathrm{w} / \mathrm{w}) \\
\text { Almond gum/PVA } \\
7 \%(\mathrm{w} / \mathrm{w})\end{array}$ & $\begin{array}{l}1.0 \\
2.0 \\
3.0 \\
4.0\end{array}$ & Water/ethanol & $\begin{array}{l}169 \pm 35 \\
151 \pm 28 \\
121 \pm 31 \\
127 \pm 29\end{array}$ & - & $\begin{array}{l}18 \mathrm{kV} \\
0.125 \mathrm{~mL} / \mathrm{h} \\
15 \mathrm{~cm}\end{array}$ & [31] \\
\hline $\begin{array}{l}\text { PLA } \\
10(\mathrm{wt} \%)\end{array}$ & $0,1,3,5,7,9$, and $11 \mathrm{wt} \%$ & $\begin{array}{l}\text { Chloroform } \\
\text { /acetone }\end{array}$ & $1500-900$ & - & $\begin{array}{l}18 \mathrm{kV} \\
0.5 \mathrm{~mL} / \mathrm{h} \\
12 \mathrm{~cm}\end{array}$ & [33] \\
\hline
\end{tabular}



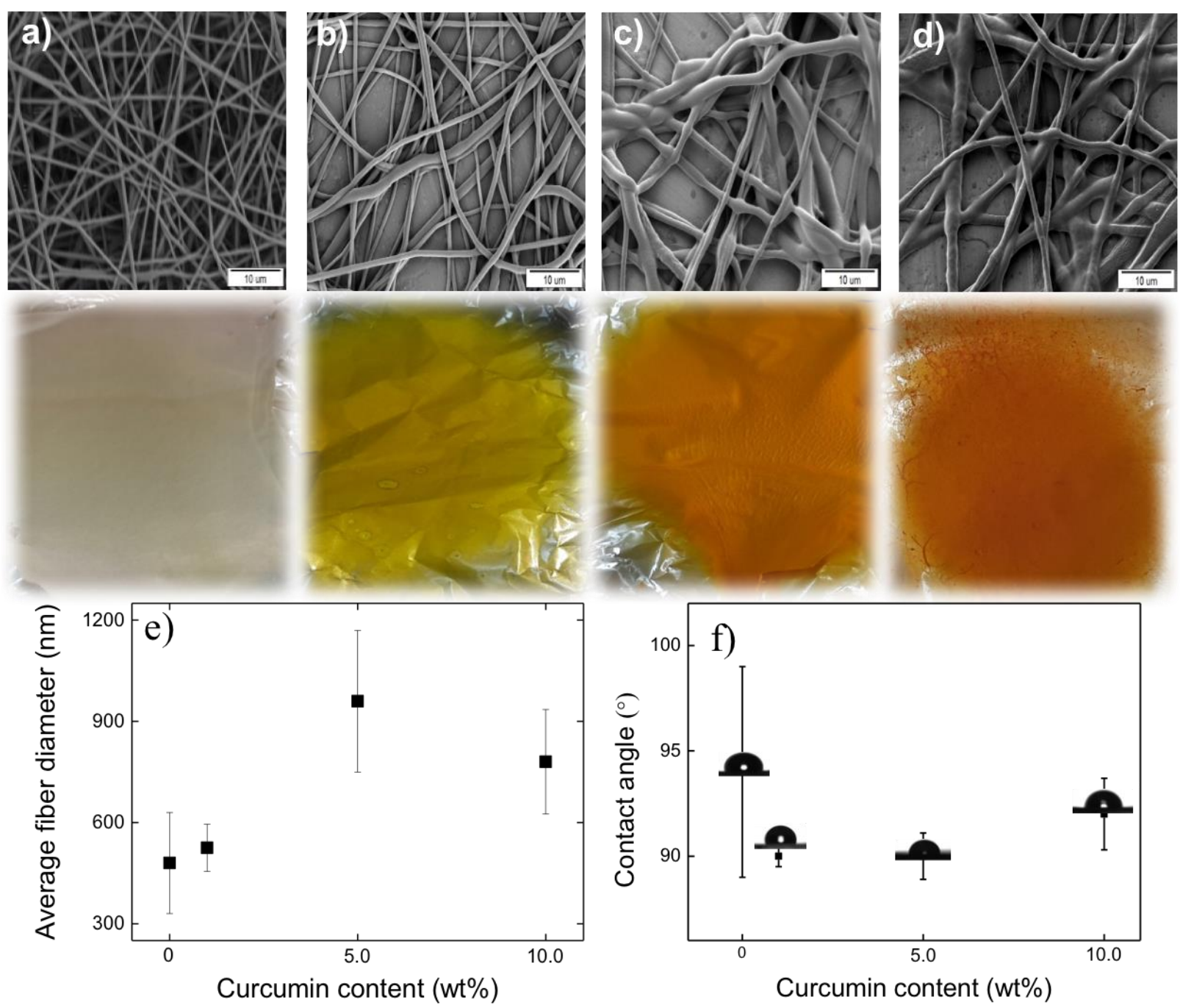

Figure 2. SEM micrographs and photographic images of the PU and PU/Cur fibers different curcumin concentrations a) 0 wt $\%$, b) $1 \mathrm{wt} \%$, c) $5 \mathrm{wt} \%$, and d) $10 \mathrm{wt} \%$. e) Average fiber diameter and f) contact angle of the fibers as functions of curcumin weight fraction. (Applied voltage: $12.5 \mathrm{kV}$, Flow rate: $1.00 \mathrm{~mL} / \mathrm{h}$, Distance: $17 \mathrm{~cm}$, PU content in PU/Cur fibers: $12.5 \mathrm{wt} \%$ ).

\section{Effect of Electrospinning Parameters on the PU/Cur fibers}

Processing variables such as applied voltage, flow rate, and tip-to-collector distance need to be considered for the fabrication of fibers. The size and hydrophilicity of the PU/Cur fibers are summarized in Table 3.

Applied voltage has a significant effect on the diameter of the PU/Cur fibers. The average fiber diameter increases from $730 \pm 160$ to $1115 \pm 225 \mathrm{~nm}$ when the applied voltage rises from 10.0 to 15.0 $\mathrm{kV}$, respectively. This applied electric field dependent increase can be explained as more polymer ejection and formation of large diameter fibers. Fallah et al. [32] showed that
PCL/gelatin/curcumin nanofibers have an increasing diameter with the increasing voltage ranging from 10 to $20 \mathrm{kV}$. In another example, Hoang et al. [30] reported the increased diameter of PCL/chitosan fibers with respect to the applied voltage $(15,18$, and $24 \mathrm{kV})$, pointing out the higher electrostatic force results in the multi-jet formation, hence the multiple fibers can stick each other and form thicker fibers. It can be noted that applied voltage affects not only the fiber diameter but also the hydrophilicity of the fibers, as shown by the contact angle values. Fibers with larger diameter resulted in a larger contact angle. Since more uniform and the least hydrophobic fibers were obtained at $12.5 \mathrm{kV}$, this value was selected to investigate the other variables in this study. 
Using different solution flow rates ranged between 1.00 and $1.50 \mathrm{~mL} / \mathrm{h}$, not any particular trend was observed in the diameter and contact angle value of the PU/Cur fibers. The diameters of the PU/Cur fibers showed first an increase then a decrease, this is probably due to the ejection of more solution from the needle, however, when the voltage is constant if electrical field is not enough for stretching of the solution, some of the solutions coming out of the needle tip drops and cannot reach the collector [32]. That is, a $12.5 \mathrm{kV}$ applied voltage is not sufficient to transport all the solution moving at a rate of $1.50 \mathrm{~mL} / \mathrm{h}$ to the collector. Therefore, the optimum flow rate was determined as $1.00 \mathrm{~mL} / \mathrm{h}$, at least under the ranges employed in this study.

As it is usually the case, increasing the distance between the needle tip and collector caused a decrease in the average fiber diameter. When the distance increases, the time for the formed fiber to reach the collector as well as the evaporation of the solvent increases, which leads to the elongation and thinning of the fibers $[34,35]$. The average diameter of the PU/Cur fibers fabricated at an applied voltage of $12.5 \mathrm{kV}$ and a flow rate of $1.00 \mathrm{~mL} / \mathrm{h}$ was shown to reduce around $30 \%$ with increasing the distance. On the other hand, varying the distance did not show any obvious effect on the contact angle values of the PU/Cur fibers.

Taking the process variables employed in this study into consideration, optimum conditions for PU/Cur fibers were determined as $12.5 \mathrm{kV}, 1$ $\mathrm{mL} / \mathrm{h}$, and $17 \mathrm{~cm}$. Therefore, these parameters were kept constant for further characterization of the fibers obtained from $5 \mathrm{wt} \%$ Cur containing $12.5 \mathrm{wt} \%$ PU/DMF solution.

Table 3. Electrospinning parameters, average fiber diameter and contact angle values of PU/Cur fibers. (PU content: $12.5 \mathrm{wt} \%$, Cur content: $5 \mathrm{wt} \%$ ).

\begin{tabular}{lllll}
\hline Parameters & & & AFD $(\mathrm{nm})$ & Contact Angle $\left({ }^{\circ}\right)$ \\
\hline $\begin{array}{l}\text { Applied voltage } \\
(\mathrm{kV})\end{array}$ & 10.0 & Flow rate: $1.00 \mathrm{~mL} / \mathrm{h}$ & $730 \pm 160$ & $91 \pm 1.0$ \\
& 12.5 & Tip-to-collector distance: $17 \mathrm{~cm}$ & $960 \pm 210$ & $90 \pm 1.1$ \\
& 15.0 & & $1115 \pm 225$ & $109 \pm 2.5$ \\
\hline $\begin{array}{l}\text { Flow rate } \\
(\mathrm{mL} / \mathrm{h})\end{array}$ & 1.00 & Applied voltage: $12.5 \mathrm{kV}$ & $960 \pm 210$ & $90 \pm 1.1$ \\
& 1.25 & Tip-to-collector distance: $17 \mathrm{~cm}$ & $1235 \pm 125$ & $91 \pm 1.0$ \\
& 1.50 & & $955 \pm 195$ & $93 \pm 2.0$ \\
\hline Tip-to-collector distance $(\mathrm{cm})$ & 14.0 & Applied voltage: $12.5 \mathrm{kV}$ & $1390 \pm 285$ & $96 \pm 1.5$ \\
& 17.0 & Flow rate: $1.00 \mathrm{~mL} / \mathrm{h}$ & $960 \pm 210$ & $90 \pm 1.1$ \\
& 20.0 & & $1000 \pm 215$ & $108 \pm 2.0$ \\
\hline
\end{tabular}

Structural Characterization of the PU/Cur fibers

X-ray diffraction (XRD) also proved the presence of curcumin particles in the PU fibers, as shown in Figure 3. The diffraction halo between $15^{\circ}$ and $30^{\circ}$ are attributed to semi-crystalline phase of the PU [36]. PU/Cur fibers have new diffraction signals at $22^{\circ}$ and $25^{\circ}$, which indicates the curcumin $[31,37]$. It is noteworthy to mention that although pure curcumin has a number of reflections between 10 and $30^{\circ},[31,37]$ the crystalline nature of curcumin in the fibers decreases because of rapid solidification during the electrospinning preventing the stretched molecular chains to form ordered crystal structures $[13,38]$. 


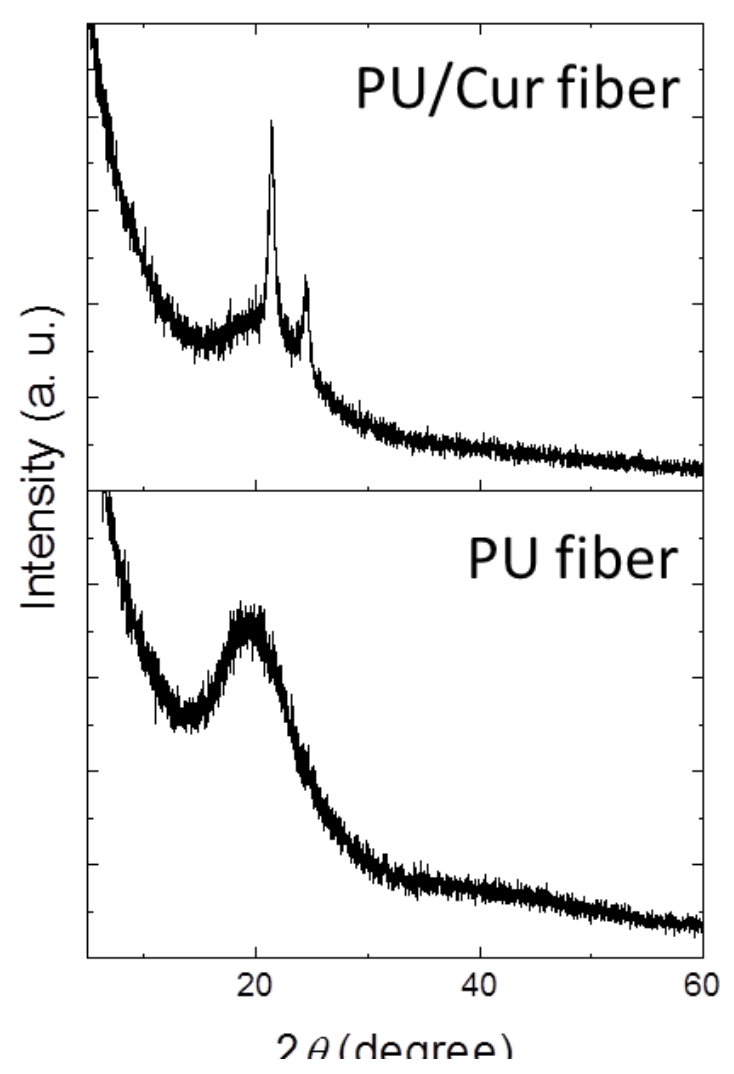

Figure 3. XRD patterns of of PU and PU/Cur fibers (PU content: $12.5 \mathrm{wt} \%$, Cur content: $5 \mathrm{wt} \%$, Applied voltage: 12.5 $\mathrm{kV}$, Flow rate: $1.00 \mathrm{~mL} / \mathrm{h}$, Distance: $17 \mathrm{~cm}$ ).
Figure 4 shows the FTIR spectra of the PU and PU/Cur fibers with the chemical structures of PU and Cur. The characteristic absorption bands of PU were observed. These are $\mathrm{C}=\mathrm{O}$ (amide I) stretching at $1729 \mathrm{~cm}^{-1}, \mathrm{O}-\mathrm{C}-\mathrm{N}$ (amide II) stretching at $1530-1595 \mathrm{~cm}^{-1}, \mathrm{~N}-\mathrm{H}$ (amide III) bending at $1260 \mathrm{~cm}^{-1}$ and $\mathrm{N}-\mathrm{H}$ stretching vibrations at $3330 \mathrm{~cm}^{-1}$. The bands appeared at $2927-2846 \mathrm{~cm}^{-1}$ due to the $\mathrm{CH}_{2}$ stretching, $\mathrm{C}-\mathrm{N}$ and $\mathrm{C}-\mathrm{O}$ stretchings at $1226 \mathrm{~cm}^{-1}, \mathrm{C}-\mathrm{O}-\mathrm{C}$ symmetric stretching vibrations at $1166 \mathrm{~cm}^{-1}$ [39]. (Figure 4a) The band around $3510 \mathrm{~cm}^{-1}$, which is attributed to the characteristic phenolic $\mathrm{OH}$ stretching vibration, was prominent in the PU/Cur (10 wt $\%)$ fibers. The disappearance of this stretching vibration with decreasing curcumin concentration and the broadening at around 3550 $-3150 \mathrm{~cm}^{-1}$ may be attributed to the formation of a hydrogen bond between curcumin and PU [28, 32]. (Figure 4b) Moreover, the strong stretching vibrations of the benzene ring at $1625 \mathrm{~cm}^{-1}$ and the olefinic $\mathrm{C}-\mathrm{H}$ bending vibration at $1452-$ $1420 \mathrm{~cm}^{-1}$ appeared in the PU/Cur (10 wt\%) fibers. The bending vibrations of the enol $\mathrm{C}-\mathrm{O}$ band at $1270 \mathrm{~cm}^{-1}$ and the $\mathrm{C}-\mathrm{H}$ bond of the alkene groups at $966 \mathrm{~cm}^{-1}$ were detected [28]. (Figure 4c)

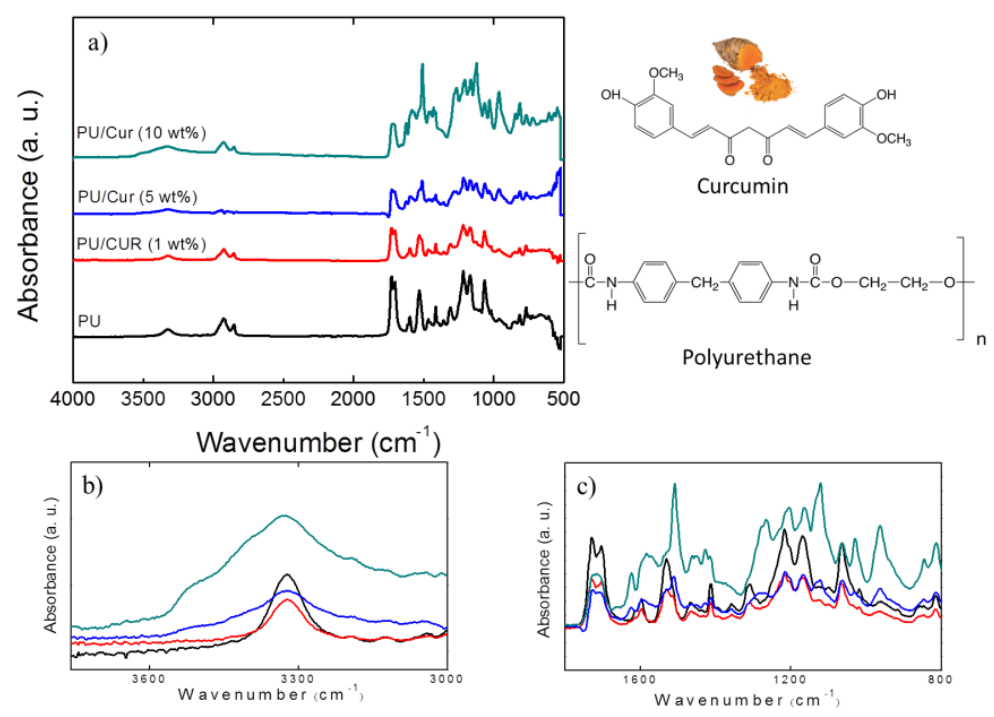

Figure 4. (a) FTIR spectra of the PU and PU/Cur fibers, (b) and (c) show the enlarged view of the spectra. 


\section{CONCLUSION}

We have shown a simple method to fabricate curcumin-loaded polyurethane (PU/cur) fibrous scaffolds, which can be further used as a wound dressing. the fiber diameters of the pu fibers ranged from 250 to $850 \mathrm{~nm}, \mathrm{PU} /$ cur fibers ranged from 525 to $960 \mathrm{~nm}$. the fabrication of fibrous scaffolds containing with the desired properties is promising for the advancement of the biomaterials to be used in various biomedical healthcare sectors. In addition, bioactive agents (such as herbal extracts, essential oils) may be good alternatives to the chemical based materials. a detailed study dealing with various essential oils, controlled bioactive agent release, cell proliferation, and cytotoxicity tests is underway.

\section{Acknowledgements}

This work was supported financially by the IKCU Scientific Research Project (2016-TYL-FEBE0036)

\section{REFERENCES}

[1]. Moura, D., M.T. Souza, L. Liverani, G. Rella, G.M. Luz, J.F. Mano, and A.R. Boccaccini, Development of a bioactive glass-polymer composite for wound healing applications. Mater. Sci. Eng. C-Mater. Biol. Appl., 76 (2017) 224-232.

[2]. Regnier, T., S. Combrinck, and W. Du Plooy, Essential oils and other plant extracts as food preservatives. (2012) 539-579.

[3]. Christaki, E., E. Bonos, I. Giannenas, and P. Florou-Paneri, Aromatic plants as a source of bioactive compounds. 2 (2012) 228-243.

[4]. Sarkic, A. and I. Stappen, Essential oils and their single compounds in cosmetics-a critical review. 5 (2018) 11.

[5]. Pizzo, P., C. Scapin, M. Vitadello, C. Florean, and L. Gorza, Grp94 acts as a mediator of curcumin-induced antioxidant defence in myogenic cells. J. Cell. Mol. Med., 14 (2010) 970-981.

[6]. Aziz, M.T.A., M.F. El-Asmar, I.N. ElIbrashy, A.M. Rezq, A.L. Al-Malki, M.A.
Wassef, H.H. Fouad, H.H. Ahmed, F.M. Taha, A.A. Hassouna, and H.M. Morsi, Effect of novel water soluble curcumin derivative on experimental type-1 diabetes mellitus (short term study). Diabetol. Metab. Syndr., 4 (2012) 30.

[7]. Lee, Y.K., W.S. Lee, J.T. Hwang, D.Y. Kwon, Y.J. Surh, and O.J. Park, Curcumin Exerts Antidifferentiation Effect through AMPK alpha-PPAR-gamma in 3T3-L1 Adipocytes and Antiproliferatory Effect through AMPK alpha-COX-2 in Cancer Cells. J. Agric. Food Chem., 57 (2009) 305310.

[8]. Jordan, W.C. and C.R. Drew, Curcumin - A natural herb with anti-HIV activity. J. Natl. Med. Assoc., 88 (1996) 333.

[9]. Wang, M.E., Y.C. Chen, I.S. Chen, S.C. Hsieh, S.S. Chen, and C.H. Chiu, Curcumin protects against thioacetamide-induced hepatic fibrosis by attenuating the inflammatory response and inducing apoptosis of damaged hepatocytes. J. Nutr. Biochem., 23 (2012) 1352-1366.

[10].Merrell, J.G., S.W. McLaughlin, L. Tie, C.T. Laurencin, A.F. Chen, and L.S. Nair, Curcumin-loaded poly(epsilon-caprolactone) nanofibres: Diabetic wound dressing with anti-oxidant and anti-inflammatory properties. Clin. Exp. Pharmacol. Physiol., 36 (2009) 1149-1156.

[11].Kumbar, S.G., R. James, S.P. Nukavarapu, and C.T. Laurencin, Electrospun nanofiber scaffolds: engineering soft tissues. Biomed. Mater., 3 (2008) 034002.

[12].Rieger, K.A., N.P. Birch, and J.D. Schiffman, Designing electrospun nanofiber mats to promote wound healing - a review. J. Mat. Chem. B, 1 (2013) 4531-4541.

[13].Horzum, N., E. Boyaci, A.E. Eroglu, T. Shahwan, and M.M. Demir, Sorption Efficiency of Chitosan Nanofibers toward Metal Ions at Low Concentrations. Biomacromolecules, 11 (2010) 3301-3308.

[14].Suwantong, O., P. Opanasopit, U. Ruktanonchal, and P. Supaphol, Electrospun 
cellulose acetate fiber mats containing curcumin and release characteristic of the herbal substance. Polymer, 48 (2007) 75467557.

[15].Unnithan, A.R., P.B.T. Pichiah, G. Gnanasekaran, K. Seenivasan, N.A.M. Barakat, Y.S. Cha, C.H. Jung, A. Shanmugam, and H.Y. Kim, Emu oil-based electrospun nanofibrous scaffolds for wound skin tissue engineering. Colloid Surf. APhysicochem. Eng. Asp., 415 (2012) 454460.

[16].Dhurai, B., S. Nachimuthu, Maheswaran, G. Kumar, and R. Babu, Electrospinning of Chitosan Nanofibres Loaded with Curcumin for Wound Healing. J. Polym. Mater., 30 (2013) 471-483.

[17].Dhurai, B., N. Saraswathy, R. Maheswaran, P. Sethupathi, P. Vanitha, S. Vigneshwaran, and V. Rameshbabu, Electrospinning of curcumin loaded chitosan/poly (lactic acid) nanofilm and evaluation of its medicinal characteristics. Front. Mater. Sci., 7 (2013) 350-361.

[18].Perumal, G., S. Pappuru, D. Chakraborty, A.M. Nandkumar, D.K. Chand, and M. Doble, Synthesis and characterization of curcumin loaded PLA-Hyperbranched polyglycerol electrospun blend for wound dressing applications. Mater. Sci. Eng. CMater. Biol. Appl., 76 (2017) 1196-1204.

[19].Mutlu, G., S. Calamak, K. Ulubayram, and E. Guven, Curcumin-loaded electrospun PHBV nanofibers as potential wound-dressing material. J. Drug Deliv. Sci. Technol., 43 (2018) 185-193.

[20].Shababdoust, A., M. Ehsani, P. Shokrollahi, and M. Zandi, Fabrication of curcuminloaded electrospun nanofiberous polyurethanes with anti-bacterial activity. Prog. Biomater., 7 (2018) 23-33.

[21].Sedghi, R., N. Sayyari, A. Shaabani, H. Niknejad, and T. Tayebi, Novel biocompatible zinc-curcumin loaded coaxial nanofibers for bone tissue engineering application. Polymer, 142 (2018) 244-255.

[22].Li, J.Z., Y. Hu, T. He, M.W. Huang, X.C. Zhang, J.Y. Yuan, Y. Wei, X.M. Dong, W.
Liu, F. Ko, and W.Y. Zhou, Electrospun Sandwich-Structure Composite Membranes for Wound Dressing Scaffolds with High Antioxidant and Antibacterial Activity. Macromol. Mater. Eng., $303 \quad$ (2018) 17002270.

[23].Sedghi, R. and A. Shaabani, Electrospun biocompatible core/shell polymer-free core structure nanofibers with superior antimicrobial potency against multi drug resistance organisms. Polymer, 101 (2016) 151-157.

[24].Reneker, D.H. and A.L. Yarin, Electrospinning jets and polymer nanofibers. Polymer, 49 (2008) 2387-2425.

[25].Maheshwari, R.K., A.K. Singh, J. Gaddipati, and R.C. Srimal, Multiple biological activities of curcumin: A short review. Life Sci., 78 (2006) 2081-2087.

[26].He, T., J.N. Wang, P.L. Huang, B.Z. Zeng, H.H. Li, Q.Y. Cao, S.Y. Zhang, Z.O. Luo, D.Y.B. Deng, H.W. Zhang, and W.Y. Zhou, Electrospinning polyvinylidene fluoride fibrous membranes containing anti-bacterial drugs used as wound dressing. Colloid Surf. B-Biointerfaces, 130 (2015) 278-286.

[27].Haider, S., Y. Al-Zeghayer, F.A.A. Ali, A. Haider, A. Mahmood, W.A. Al-Masry, M. Imran, and M.O. Aijaz, Highly aligned narrow diameter chitosan electrospun nanofibers. J. Polym. Res., 20 (2013) 105.

[28].Tsekova, P.B., M.G. Spasova, N.E. Manolova, N.D. Markova, and I.B. Rashkov, Electrospun curcumin-loaded cellulose acetate/polyvinylpyrrolidone fibrous materials with complex architecture and antibacterial activity. Mater. Sci. Eng. CMater. Biol. Appl., 73 (2017) 206-214.

[29].Zhang, X., F. Shi, J. Niu, Y.G. Jiang, and Z.Q. Wang, Superhydrophobic surfaces: from structural control to functional application. J. Mater. Chem., 18 (2008) 621-633.

[30].Hoang, M.S., D. N.H., and H. D.P., Fabrication of Curcumin Loaded Nano Polycaprolactone/Chitosan Nonwoven Fabric via Electrospinning Technique. J. Sci. Technol., 55 (2017) 99-108. 
[31].Rezaei, A. and A. Nasirpour, Encapsulation of curcumin using electrospun almond gum nanofibers: fabrication and characterization. Int. J. Food Prop., 21 (2018) 1608-1618.

[32].Fallah, M., S.H. Bahrami, and M. RanjbarMohammadi, Fabrication and characterization of $\mathrm{PCL} /$ gelatin/curcumin nanofibers and their antibacterial properties. J. Ind. Text., 46 (2016) 562-577.

[33].Moradkhannejhad, L., M. Abdouss, N. Nikfarjam, S. Mazinani, and P. Sayar, Electrospun curcumin loaded poly (lactic acid) nanofiber mat on the flexible crosslinked PVA/PEG membrane film: Characterization and in vitro release kinetic study. 18 (2017) 2349-2360.

[34].Matabola, K.P. and R.M. Moutloali, The influence of electrospinning parameters on the morphology and diameter of poly(vinyledene fluoride) nanofibers- effect of sodium chloride. J. Mater. Sci., 48 (2013) 5475-5482.

[35].Haider, A., S. Haider, and I.K. Kang, A comprehensive review summarizing the effect of electrospinning parameters and potential applications of nanofibers in biomedical and biotechnology. Arab. J. Chem., 11 (2018) 1165-1188.

[36].Maleknia, L., M. Dilamian, M.K. Pilehrood, H. Sadeghi-Aliabadi, and A.H. Hekmati, Preparation, process optimization and characterization of core-shell polyurethane/chitosan nanofibers as a potential platform for bioactive scaffolds. Res. Pharm. Sci., 13 (2018) 273-282.

[37].Sun, X.Z., G.R. Williams, X.X. Hou, and L.M. Zhu, Electrospun curcumin-loaded fibers with potential biomedical applications. Carbohydr. Polym., 94 (2013) 147-153.

[38].Zhou, Y.S., D.Z. Yang, X.M. Chen, Q. Xu, F.M. Lu, and J. Nie, Electrospun watersoluble carboxyethyl chitosan/poly(vinyl alcohol) nanofibrous membrane as potential wound dressing for skin regeneration. Biomacromolecules, 9 (2008) 349-354.

[39].Dias, R.C.M., A.M. Goes, R. Serakides, E. Ayres, and R.L. Orefice, Porous Biodegradable Polyurethane Nanocomposites: Preparation, Characterization, and Biocompatibility Tests. Mater. Res.-Ibero-am. J. Mater., 13 (2010) 211-218. 